\title{
KESETARAAN GENDER DALAM PERSPEKTIF SEJARAH ISLAM
}

\author{
Viky Mazaya \\ Pegiat Studi Gender dan Anak Kab. Demak \\ email: mazaya90@gmail.com
}

\begin{abstract}
Abstrak
Persoalan gender menjadi diskursus yang senantiasa menarik hingga saat ini. Dalam konteks sejarah, munculnya persoalan gender seringkali bermuara pada kisah penciptaan Adam dan Hawa. Sekalipun kisah tentang diciptakannya Hawa yang berasal dari tulang rusuk Adam telah banyak dikritisi, namun masih banyak yang memegang teguh kisah tersebut. Kedudukan dan peran wanita mengalami pasang surut sesuai dengan konteks masyarakatnya. Pada Masa Islam dikategorikan dengan tiga masa yaitu, kalsik, pertengahan, dan modern, yang masing memiliki karakteristiknya sendiri.
\end{abstract}

Kata Kunci: kesetaraan, gender, sejarah Islam

\section{A. Pendahuluan}

Sejarah penciptaan manusia tidak terlepas dari kisah Adam dan Hawa. Kata Adam sering kali mewakili jenis kelamin laki-laki dan Hawa mewakili jenis kelamin perempuan. Perempuan merupakan salah satu makhluk ciptaan Allah yang dipasangkan dengan manusia dengan jenis kelamin laki-laki. Sejak pertama kali diciptakannya manusia, Adam diciptakan berpasangan dengan Hawa. Namun, ketika membicarakan tentang kesetaraan gender antara perempuan dan laki-laki, seringkali kisah yang menyebutkan bahwa Hawa diciptakan dari tulang rusuk Adam dan peristiwa diturunkannya Adam dan Hawa ke bumi karena memakan buah khuldi dipahami secara berbeda-beda sehingga menjadi suatu perdebatan terkait persoalan kesetaraan perempuan dan laki-laki.

Sejarah Islam mencatat, kedudukan dan peran wanita mengalami pasang surut sesuai dengan budaya masyarakat yang berlaku dalam masanya. Pada 
masa pra-Islam posisi perempuan berbeda dengan masa Islam. Pada masa Islam dapat dikategorikan menjadi 3 masa yakni masa klasik, pertengahan, dan modern.

Dalam pernikahan, banyak jenis pernikahan dalam budaya bangsa Arab masa pra Islam yang kebanyakan sangat merugikan dan menindas kaum perempuan. Kaum perempuan tidak dihargai, dalam pernikahan hanya dijadikan sebagai barang komoditi yang bisa diwariskan atau dipertukarkan tanpa ada kesepakatan terlebih dahulu dari pihak perempuan. Banyak hal terkait dengan gender diantaranya; perempuan dalam keluarga, sebagai kepala Negara, dan lain-lain. Berkat hadirnya Nabi Muhammad yang membawa ajaran Islam kedudukan perempuan dimulyakan, diangkat harkat dan martabatnya, dan mendapat hak-hak sebagai manusia.

Artikel ini membahas perjalanan perempuan sepanjang sejarah Islam dalam kaitan gender-nya terjadi kesetaraan atau justru mengalami ketidakadilan gender.

\section{B. Konsep tentang Jender}

Kata gender berasal dari bahasa Inggris, gender yang berarti jenis kelamin. Dalam Webster's New World Dictionary, gender diartikan sebagai perbedaan yang tampak antara laki-laki dan perempuan dilihat dari segi nilai dan tingkah laku. Di dalam Women's Studies Encyclopedia dijelaskan bahwa gender adalah suatu konsep kultural yang berupaya membuat pembedaan (distinction) dalam hal peran, perilaku, mentalitas, dan karakteristik emosional antara laki-laki dan perempuan yang berkembang dalam masyarakat.

Hilary M. Lips dalam bukunya yang terkenal Sex \& Gender: an Introduction mengartikan gender sebagai harapan-harapan budaya terhadap laki-laki dan perempuan (cultural expectations for women and men). H.T. Wilson dalam Sex and Gender mengartikan gender sebagai suatu dasar untuk menentukan perbedaan sumbangan laki-laki dan perempuan pada kebudayaan dan kehidupan kolektif yang sebagai akibatnya mereka menjadi laki-laki dan perempuan. ${ }^{1}$

${ }^{1}$ Nasaruddin Umar, Argumen Kesetaraan Jender Perspektif al-Qur'an, (Jakarta: Paramadina, 2001), hlm. 34 . 
Mansour Faqih dalam bukunya Analisis Gender \& Transformasi Sosial mengemukakan konsep gender yakni suatu sifat yang melekat pada kaum laki-laki maupun perempuan yang dikonstruksi secara sosial maupun cultural. Misalnya bahwa perempuan itu dikenal lemah lembut, cantik, emosional, atau keibuan. Sementara laki-laki dianggap kuat, rasional, jantan, perkasa. Ciri dari sifat itu sendiri merupakan sifat-sifat yang dapat dipertukarkan. ${ }^{2}$

Berdasarkan definisi di atas maka dapat disimpulkan bahwa gender adalah peran antara laki-laki dan perempuan yang merupakan hasil konstruksi sosial budaya. Suatu peran maupun sifat dilekatkan kepada lakilaki karena berdasarkan kebiasaan atau kebudayaan biasanya peran maupun sifat tersebut hanya dilakukan atau dimiliki oleh laki-laki dan begitu juga dengan perempuan. Suatu peran dilekatkan pada perempuan karena berdasarkan kebiasaan atau kebudayaan yang akhirnya membentuk suatu kesimpulan bahwa peran atau sifat itu hanya dilakukan oleh perempuan.

Sex (dalam kamus bahasa Indonesia juga berarti “jenis kelamin") lebih banyak berkonsentrasi kepada aspek biologi seseorang, meliputi perbedaan komposisi kimia dan hormon dalam tubuh, anatomi fisik, reproduksi, dan karakteristik biologis lainnya. Sementara gender lebih banyak berkonsentrasi kepada aspek sosial, budaya, psikologis, dan aspek-aspek non biologis lainnya. Gender secara umum digunakan untuk mengidentifikasi perbedaan laki-laki dan perempuan dari segi sosial-budaya. Sementara itu, sex secara umum digunakan untuk mengidentifikasi perbedaan laki-laki dan perempuan dari segi anatomi biologi. ${ }^{3}$

Dari definisi di atas dapat disimpulkan bahwa perbedaan antara sex dan gender yakni "sex" membedakan laki-laki dan perempuan dilihat dari ciri-ciri biologis yang merupakan ketentuan Tuhan yang disebut kodrat. Sedangkan "gender" membedakan laki-laki dan perempuan berdasarkan aspek sosial,

2 Mansour Faqih, Analisis Gender E Transformasi Sosial, (Yogyakarta: Pustaka Pelajar, 2007), hlm. 7.

${ }^{3}$ Nasaruddin Umar, Argumen Kesetaraan Jender..., hlm. 35. 
budaya, psikologis, dan aspek non biologis lainnya, bisa dipertukarkan dan bukan merupakan kodrat Tuhan.

Perbedaan biologis antara laki-laki dan perempuan juga bisa dilihat sebagaimana yang dijelaskan Mansour Faqih bahwa manusia jenis laki-laki adalah manusia yang memiliki atau bersifat seperti daftar berikut ini: lakilaki adalah manusia yang memiliki penis, memiliki jakala (kalamenjing) dan memproduksi sperma. Sedangkan perempuan memiliki alat reproduksi seperti rahim dan saluran untuk melahirkan, memproduksi telur, memiliki vagina, dan mempunyai alat menyusui. Alat-alat tersebut secara biologis melekat pada manusia jenis perempuan dan laki-laki selamanya. Artinya secara biologis alat-alat tersebut tidak bisa dipertukarkan antara alat biologis yang melekat pada manusia laki-laki dan perempuan. Secara permanen tidak berubah dan merupakan ketentuan biologis atau sering dikatakan sebagai ketentuan Tuhan atau kodrat. ${ }^{4}$

\section{Sejarah Penciptaan Manusia Pertama Kali}

Cerita penciptaan dalam al Qur'an tidak hanya terdapat dalam surat an-Nisa' ayat 1 tetapi juga terdapat dalam tiga puluh ayat lainnya.

"Hai sekalian manusia, bertakwalah kepada Tuhan-mu yang telah menciptakan kamu dari seorang diri, dan dari padanya Allah menciptakan isterinya; dan dari pada keduanya Allah memperkembang biakkan laki-laki dan perempuan yang banyak. dan bertakwalah kepada Allah yang dengan (mempergunakan) nama-Nya kamu saling meminta satu sama lain, dan (peliharalah) hubungan silaturrahim. Sesungguhnya Allah selalu menjaga dan mengawasi kamu." (QS. al-Nisa' [4]: 1)

Menurut Riffat Hasan, dari 30 ayat tentang penciptaan, ada 3 istilah yang digunakan untuk kemanusiaan (al-nas, basyar, dan al-insan). Dari ketiga istilah tersebut, tidak satu pun yang merujuk pada diri laki-laki (male person). Jadi, di sini tidak memiliki alasan yang tepat untuk menafsirkan bahwa ciptaan pertama adalah Adam sebagai manusia laki-laki, tetapi lebih tepat adalah diri manusia.

\footnotetext{
${ }^{4}$ Mansour Faqih, Analisis Gender..., hlm. 7-8.
} 
Dari sisi kriteria etis, penafsiran mufassir (al-Thabari dan al-Razi) memang kurang menunjukkan itu, karena tidak disandarkan pada keadilan dan kesetaraan. Dalam tradisi Islam, al-Qur'an adalah "kalam Tuhan" yang dipercayai harus merefleksikan keadilan. Penafsiran nafs wahidah sebagai Adam, pada akhirnya mengimplikasikan ketidakadilan gender. Yang mengkhawatirkan, ayat tersebut dijadikan sebagai tulang punggung atau tolak ukur setiap penafsiran terhadap ayat-ayat lain yang berkaitan dengan hubungan laki-laki dan perempuan. Oleh karena perempuan diciptakan dari laki-laki, maka perempuan subordinat dari laki-laki. Dengan demikian, penafsiran yang menyatakan bahwa hawa diciptakan dari tulang rusuk Adam telah keluar dari standar etis,karena Tuhan tidak mungkin berlaku tidak adil. ${ }^{5}$

Dari kedua pendapat di atas, argumen yang pertama yakni dari Riffat Hasan. Yang perlu digarisbawahi dari pendapatnya adalah Rifat Hasan beranggapan bahwa Hawa tidak diciptakan dari Adam tetapi Hawa dan Adam sama-sama diciptakan dari diri yang sama yaitu diri manusia karena merujuk istilah yang dipakai dalam al-Qur'an yang tidak merujuk pada salah satu jenis laki-laki ataupun perempuan. Pendapat ini jelas menolak subordinasi terhadap perempuan dalam proses penciptaan manusia. Sedangkan pendapat yang pendapat yang kedua dari al-Thabari, penafsirannya terkait ayat penciptaan manusia dan Hadits Nabi yang menyebutkan bahwa perempuan diciptakan dari tulang rusuk Adam. Banyak pihak menganggap telah menyebabkan timbulnya ketidakadilan gender. Pendapat ini bertolak belakang dengan pendapat Riffat Hasan.

Perlu kiranya dalam memahami sejarah penciptaan dipahami tidak hanya dari satu atau dua sisi pendapat saja. Dalam hal ini penulis menemukan argumen yang mematahkan pendapat Riffat Hasan dan lebih condong kepada pendapatnya al-Thabari tentang penciptaan perempuan pertama kali (ibu Hawa) dari tulang rusuk Adam tetapi tidak bermaksud menjadikan subordinasi perempuan. Penulis beranggapan bahwa pendapat ketiga ini lebih kuat karena didasarkan pada penelitian ilmiah. Penelitian

\footnotetext{
${ }^{5}$ Nurjannah Ismail, Perempuan dalam Pasungan Bias Laki-laki dalam Penafsiran, (Yogyakarta: LKiS, 2003), hlm. 334-335.
} 
biologi mutakhir yang mengakui bahwa tidak seluruh gender betina (perempuan) tidak memilki kromosom Y. Ada sebagian sangat kecil dari mereka yang memilikinya. Jadi jangan coba-coba mendirikan Jurassic Park, potensi untuk sintas akan selalu ada. Fakta mutakhir itu juga menjelaskan fenomena transeksual (banci).

Nabi Adam memiliki kromosom X dan Y, sehingga darinya dapat dikloningkan sosok berkromosom XY (lelaki) maupun XX (perempuan). Namun "cloning" di langit itu lebih maju, karena tidak memerlukan masa tunggu yang lama sampai buah kloning (ibunda Hawa) menjadi dewasa dan layak menjadi pasangan hidup Nabi Adam. ${ }^{6}$

Bahan dasar untuk melakukan cloning dinamai sel tunas (stem cell). Sel tunas dapat duperoleh dari janin (embrio) atau sum-sum tulang. Sum-sum tulang yang paling baik adalah yang berusia muda. Sumsum muda ini bisa saja didapatkan dari bagian rawan tulang rusuk. Jelaslah kini makna mereka (kaum perempuan) diciptakan dari tulang rusuk dalam hadis Nabi. Kloning pula barangkali yang dimaksud dengan belahan saat Nabi bersabda, "kaum perempuan adalah belahan (saudara/mitra) kaum laki-laki".

Dari penjelasan tersebut, memberikan gambaran bagi kita semua bahwa yang disebutkan dalam hadis bahwa Hawa diciptakan dari tulang rusuk Adam merupakan hal yang logis. Ketika diterjemahkan ke dalam bahasa biologi adalah proses cloning. Tetapi cloning yang sudah sangat canggih karena dilakukan oleh Tuhan. Lebih lanjut lagi penulis buku tersebut menyebutkan bahwa hasil cloning tersebut merupakan mitra. ${ }^{7}$ Sebagai mitra tidak ada yang unggul satu sama lain tetapi keduanya setara dan harus saling menghargai.

Terdapat banyak perbedaan pendapat dalam menafsirkan dalil tentang penciptaan manusia. Perbedaan penafsiran di kalangan mufassir diantaranya karena berbeda latar belakang pemikiran, kondisi sosial keagamaan, dan metode yang mereka gunakan. ${ }^{8}$

${ }^{6}$ Ronni Starda, Sabda Nabi tentang Perempuan, Serumpun Bunga dari Rasulullah, (Jakarta: Elex Media Komputindo, 2010), hlm. 23.

${ }^{7}$ Ronni Starda, Sabda Nabi tentang Perempuan..., hlm. 24.

${ }^{8}$ Nurjannah Ismail, Perempuan dalam Pasungan..., hlm. 336. 


\section{Kedudukan Perempuan pada Zaman sebelum Islam}

Pada zaman pra-Islam terdapat beberapa kebudayaan zaman jahiliyyah, salah satunya yaitu kebiasaan membunuh anak perempuan. Quraish Shihab menyebutkan tiga alasan terjadinya pembunuhan pada zaman jahiliyyah. Pertama, orang tua pada masa masyarakat jahiliyah takut jatuh miskin bila menanggung biaya hidup anak perempuan yang dalam konteks zaman itu, tidak bisa mandiri dan produktif. Kedua, masa depan anak-anak dikhawatirkan mengalami kemiskinan (jatuh miskin). Anak perempuan dikubur karena orang tuanya khawatir anak-anak perempuan diperkosa atau berzina. Ketiga, sesuai dengan seringnya konflik antar kabilah atau peperangan antarsuku, orang tua khawatir anaknya akan ditawan musuh dalam peperangan itu. ${ }^{9}$

Alasan mereka bahwa anak perempuan adalah biang dari petaka karena dari segi fisik perempuan lebih lemah daripada laki-laki. Ketika lemah, secara otomatis akan menjadi batu sandungan bagi sang ayah atau ketua kelompok dan tidak bisa diajak berperang. Dan akan mengurangi pengaruh kabilahnya dalam percaturan dunia, penghambat pembangunan, kurang bisa mandiri dan menggantungkan pada laki-laki dan itu semua adalah aib bagi mereka maka harus ditutupi kalau perlu dibuang. Dengan fenomena tersebut, hak-hak perempuan tidak terpenuhi bahkan tidak akan terpenuhi. Penghormatan dan pengagungan kaum perempuan berubah menjadi pelecehan seksual dan psikologi. Inilah salah satu yang ditentang Islam sesuai dengan firman Allah, "Sesungguhnya yang paling mulia di sisi Allah adalah yang paling bertakwa"10

Menurut Quraish Shihab, catatan terpenting yang ingin ia sampaikan ialah bahwa tradisi mengubur anak perempuan hidup-hidup bukan adat yang memperoleh restu dari semua kabilah Arab Jahiliyyah karena kenyataannya, sebagian kabilah justru memberikan tebusan berupa unta bagi orang tua yang bermaksud mengubur anak perempuannya. Sha'sha'ah bin Najiah, kakek al-

\footnotetext{
${ }^{9}$ Mohammad Monib dan Islah Bahrawi, Islam dan Hak Asasi Manusia dalam Pandangan Nurcholish Madjid, (Jakarta: Gramedia Pustaka Utama, 2011), hlm. 134.

${ }^{10}$ Fatah Syukur, Sejarah Peradaban Islam, (Semarang: Pustaka Rizki Putra, 2011), hlm. 21.
} 
Farazdaq, penyair kenamaan zaman Jahiliyyah, yang memberikan dua ekor unta hamil sepuluh bulan kepada orang tua yang akan membunuh anak perempuannya. Konon, ia sempat menyelamatkan sekitar 300-400 orang anak perempuan yang akan dikubur hidup-hidup dengan tebusan unta. ${ }^{11}$

Walaupun masih ada kabilah yang kontra terhadap penguburan hidup-hidup bayi perempuan tetapi kebiasaan tersebut sudah menjadi budaya yang mengakar dan sudah umum dipraktekkan oleh masyarakat Arab Jahiliyyah pada masa itu.

Adat-istiadat Jahiliyah yang berlaku pada masa itu, selain mengubur hidup-hidup setiap bayi perempuan yang dilahirkan,yaitu mengawini perempuan sebanyak yang disukai dan menceraikan mereka sesuka hati, sampai pernah ada kepala suku yang mempunyai tujuh puluh hingga sembilan puluh istri. Sebagaimana dimaklumi, masyarakat Arab zaman Jahiliyyah mempraktekkan bermacam-macam pola perkawinan. Ada yang disebut nikah ad-dayzan, dimana anak sulung laki-laki dibolehkan menikahi janda (istri) mendiang ayahnya. Caranya sederhana, cukup dengan melemparkan sehelai kain kepada wanita itu, maka saat itu juga dia sudah mewarisi ibu tirinya itu sebagai istri. Kadangkala dua orang bapak saling menyerahkan putrinya masing-masing kepada satu sama lain untuk dinikahinya. Praktek ini mereka namakan nikah as-syighr. Ada juga yang saling bertukar istri hanya dengan kesepakatan kedua suami tanpa perlu membayar mahar, yaitu nikah al-badal. Selain itu ada pula yang dinamakan zawaj al istibdha', dimana seorang suami boleh dengan paksa menyuruh istrinya untuk tidur dengan lelaki lain sampai hamil dan setelah hamil sang istri dipaksa untuk kembali kepada suaminya semula, semata-mata karena mereka ingin mendapatkan bibit unggul dari orang lain yang dipandang mempunyai keistimewaan tertentu. Bentuk-bentuk pernikahan semacam ini jelas sangat merugikan dan menindas perempuan. ${ }^{12}$ Ada juga jenis pernikahan yang disebut dengan nikah al-mukhadanah, yaitu pernikahan seorang wanita yang

\footnotetext{
${ }^{11}$ Mohammad Monib dan Islah Bahrawi, Islam dan Hak Asasi Manusia..., hlm. 134.

${ }^{12}$ Syamsuddin Arif, Orientalis \& Diabolisme Pemikiran, (Jakarta: Gema Insani, 2008), hlm. $110-111$.
} 
mempunyai banyak suami (poliandri). Hal seperti ini banyak terjadi antar saudara di kalangan bangsa Arab. ${ }^{13}$

Musdah Mulia menambahkan, beribu tahun sebelum Islam diwahyukan, di berbagai belahan dunia kaum perempuan dipandang tidak memiliki kemanusiaan yang utuh dan oleh karenanya perempuan tidak berhak bersuara, tidak berhak berkarya, dan tidak berhak memiliki harta. Bahkan, eksistensinya sebagai makhluk manusia pun dipertanyakan. ${ }^{14}$

Dari uraian tersebut dapat dilihat bahwa kaum perempuan pada masa pra-Islam atau yang lebih dikenal dengan zaman Jahiliyyah terlihat jelas praktik-praktik kehidupan yang ada belum menunjukkan kesetaraan gender. Hal ini disebabkan kaum laki-laki Arab jahiliyyah belum memahami hak-hak asasi manusia khususnya hak-hak perempuan. Perempuan dianggap hina dengan alasan berbagai kelemahan-kelemahannya. Padahal kelemahan perempuan itu bukan karena memang tidak mampu tetapi karena keterbatasan para perempuan yang tidak diberi ruang gerak untuk mengaktualisasikan diri.

\section{E. Kesetaraan Genderdalam Perspektif Sejarah Islam}

Kesetaraan gender dalam perspektif sejarah Islam dapat dikategorikan dalam tiga periode yakni, periode klasik, pertengahan, dan modern.

\section{Periode Klasik}

Pada masa Rasulullah, kaum perempuan muslimah tampak dalam sosok perempuan yang dinamis, sopan, dan terpelihara akhlaknya. Bahkan dalam al Qu'an, figur ideal seorang muslimah disimbolkan sebagai pribadi yang memiliki kemandirian politik, al-istiqlāl al-siyāsah (QS. al-Mumtahanah [60]: 12), seperti figur Ratu Bilqis yang mempunyai kerajaan 'arsyun 'azhim (superpower), dan figur-figur yang lain. ${ }^{15}$

\footnotetext{
${ }^{13}$ Nasy'at Al Masyri. Penerjemah:Salim Basyarahil. Nabi Suami Teladan, (Jakarta: Gema Insani Press. 1989), hlm. 18

14 Siti Musdah Mulia, "Kekerasan terhadap Perempuan Mencari Akar Kekerasan dalam Teologi", SAWWA Jurnal Studi Gender, PSG IAIN Walisongo, Semarang, Vol. 3, No. 1, 2008, hlm. 12 .

${ }^{15}$ Siti Musdah Mulia, “Kekerasan terhadap Perempuan...”, hlm. 14.
} 
Gambaran yang demikian ideal ini tidak ditemukan dalam kitab-kitab suci agama lain. Tidaklah mengherankan jika pada masa Nabi ditemukan sejumlah perempuan memiliki kemampuan prestasi cemerlang sebagaimana yang diraih kaum laki-laki. Dalam jaminan al-Qur'an, perempuan dengan leluasa memasuki semua sector kehidupan masyarakat, termasuk politik dan ekonomi. ${ }^{16}$

Ada sebuah hadits yang cukup popular dan seringkali dijadikan dalil yang menganggap bahwa tidak akan beruntung satu kaum bila diserahkan kepada perempuan. Padahal anggapan tersebut adalah salah kaprah karena menggeneralisasi kasus tertentu yang sebenarnya berlaku hanya untuk kondisi yang dimaksud dalam hadits tersebut. Berikut terjemahan hadits yang saya kutip di buku Wawasan al-Qur'an karya Quraish Shihab.

"Ketika Rasulullah SAW. Mengetahui bahwa masyarakat Persia mengangkat putri Kisra sebagai penguasa mereka, beliau bersabda, "Tidak akan beruntung satu kaum yang menyerahkan urusan mereka kepada perempuan." (Diriwayatkan oleh Bukhari, al-Nasa'i, dan Ahmad melalui Abu Bakrah).

Hadits tersebut di atas ditujukan kepada masyarakat Persia ketika itu, bukan tehadap semua masyarakat dan dalam semua urusan. Quraisy Shihab menyimpulkan bahwa tidak ditemukan satu ketentuan agama pun yang dapat dipahami sebagai larangan keterlibatan perempuan dalam bidang politik, atau ketentuan agama yang membatasu bidang tersebut hanya untuk kaum lelaki. Di sisi lain, cukup banyak ayat dan hadits yang dapat dijadikan dasar pemahaman untuk menetapkan adanya hak-hak tesebut. ${ }^{17}$

Dalam sejarah Islam, peran perempuan dalam sektor publik dapat dibuktikan dalam kisah istri-istri Nabi. Kita menemukan di dalam Shahih Bukhori, salah satu kumpulan hadits yang otentik, menyebutkan bahwa perempuan muslim secara aktif membantu mereka yang luka dalam perang Uhud, termasuk di dalam kaum perempuan ini adalah para istri Nabi sendiri. Satu orang menggambarkan bahwa ia melihat Aisyah dan istri Nabi

\footnotetext{
${ }^{16}$ Siti Musdah Mulia, “Kekerasan terhadap Perempuan...", hlm. 15.

17 Quraisy Shihab, Wawasan al-Qur'an: Tafsir Tematik atas Pelbagai Persoalan Umat, (Jakarta: Mizan, -), hlm. 416.
} 
yang lain membawa air untuk kaum laki-laki di medan perang. ${ }^{18}$ Aisyah meriwayatkan hadits bahwa dia (Aisyah) menemani Nabi dalam sebuah perang, dan ini terjadi setelah turunnya ayat tentang cadar. ${ }^{19}$ Azyumardi Azra menyebutkan bahwa, pada zaman Nabi Muhammad SAW., belum ada larangan perempuan menjadi pemimpin. Bahkan Aisyah (istri Nabi) saja pernah menjadi pemimpin perang. ${ }^{20}$

Maka sangat wajar jika dalam lintas sejarah umat Islam terdapat tokoh perempuan yang berperan sebagai pemimpin, tokoh ulama, dan perawi hadits. Pada masa Nabi, tercatat ada 1.232 perempuan yang menerima dan meriwayatkan hadits. Bahkan Ummul Mukminin Aisyah ra. tercatat sebagai salah seorang dari tujuh bendaharawan hadits. Beliau meriwayatkan 2.210 hadits. Khadijah binti Khuwailid, istri Nabi yang pertama, dikenal sebagai perempuan yang sukses dalam dunia bisnis. Al-Syifa' tercatat sebagai perempuan yang ditunjuk Khalifah Umar sebagai manajer pasar di Madinah, sebuah pasar besar di ibu kota pada waktu itu. Zainab, istri Nabi, menyamak kulit dan hasilnya disedekahkan. Zainab istri Ibn Mas'ud dan Ama' binti Abu Bakar keluar rumah mencari nafkah untuk keluarga. Di Medan perang, banyak nama sahabat perempuan yag tercatat sebagai pejuang, baik di garis belakang seperti mengobati prajurit yang luka dan menyediakan logistik maupun di garis depan memegang senjata berhadapan dengan lawan. Nusaibah binti Ka'ab tercatat sebagai perempuan yang memanggul senjata melindungi Rasululah ketika perang Uhud. Al-Rabi' binti al-Mu'awwidz, Ummu Sinan, Ummu Sulaim, Ummu Athiyah, dan sekelompok perempuan lain juga beberapa kali ikut turun ke medan laga. Catatan mengenai keberanian mereka dapat kita jumpai dalam banyak hadits shahih dan buku-buku sejarah yang terkenal. ${ }^{21}$

Akan tetapi, sejarah mencatat bahwa kedudukan perempuan pasca Nabi bukan semakin membaik, melainkan semakin jauh dari kondisi ideal.

${ }^{18}$ Asghar Ali Engineer, Pembebasan Perempuan, (Yogyakarta: LKiS, 1999), hlm. 267.

${ }^{19}$ Asghar Ali Engineer, Pembebasan Perempuan, hlm. 270.

${ }^{20}$ Azyumardi Azra, Islam Substantif: Agar Umat Tidak Jadi Buih, (Jakarta: Mizan. 2000),

${ }^{21}$ Said Aqil Siraj, Tasawuf Sebagai Kritik Sosial , (Bandung: Mizan, 2006), hlm. 247. 
Sepeninggal Nabi, perempuan mukmin kembali mengalami mengalami eksklusi dari ruang publik. Hal itu mengindikasikan bahwa umat Islam pasca Nabi tak sepenuhnya berhasil menepis bias-bias patriarkhi yang secara kuat mengakar dalam masyarakat Arab pra-Islam, dan di berbagai masyarakat lainnya dimana Islam tersiar. ${ }^{22}$

Beberapa kaum feminis radikal menuduh bahwa ajaran Islam yang tertuang dalam ayat-ayat gender menyebabkan subordinasi perempuan sehingga menimbulkan ketidakadilan gender yang merugikan pihak perempuan. Syekh Abdul Halim Muhammad Abu Syuqqoh dalam karya monumentalnya, Tahrir al-Mar'ah $f i$ 'Ashr al-Risalah, misalnya, membuktikan bahwa tidak seperti yang sering dituduhkan, agama Islam ternyata sangat emansipatoris. Setelah melakukan studi intensif atas literature Islam Klasik, beliau mendapati bahwa kedatangan Islam telah menyebabkan terjadinya revolusi gender pada abad ke-7 Masehi. Agama samawi terakhir ini justru datang memerdekakan perempuan dari dominasi kultur Jahiliyyah yang dikenal sangat zalim dan biadab itu. Abu Syuqqah juga menemukan bahwa pasca datangnya Islam kaum wanita mulai diakui hak-haknya sebagai layaknya manusia dan warga Negara (bukan sebagai komoditi), terjun dan berperan aktif dalam berbagai sektor, termasuk politik dan militer. Kesimpulan senada juga dicapai oleh para peneliti Barat. Setelah ditelusuri dan diteliti lebih jauh, maka didapati bahwa ternyata kaum wanita pada zaman Nabi Muhammad SAW lebih maju dan diakui hak-hak asasinya ketimbang pada masa pra-Islam.

Oleh karena itu tidaklah berlebihan jika dikatakan bahwa gerakan emansipasi perempuan dalam sejarah peradaban manusia sebenarnya dipelopori oleh risalah yang dibawa Nabi Muhammad SAW. Kedatangan Islam telah mengeliminasi budaya-budaya Jahiliyyah dan dihapuskan untuk selama-lamanya. ${ }^{23}$

${ }^{22}$ Siti Musdah Mulia, “Kekerasan terhadap Perempuan...”, hlm. 15.

${ }^{23}$ Arif, Syamsuddin, "Wanita dan Keluarga Citra Sebuah Peradaban" dalam Al Insan, Jurnal Kajian Islam, Lembaga Kajian dan Pengembangan Al Insan, Jakarta, N0. 3, Vol. 2, 2006, hlm. 95-96. 
Islam hadir membawa perubahan yang lebih baik yang dikemas dalam kitab suci al-Qur'an. Menurut Nasaruddin Umar, ada beberapa variabel yang dapat digunakan sebagai standar dalam menganalisa prinsip-prinsip kesetaraan gender dalam al-Qur'an. Variabel-variabel tersebut antara lain:

\section{a. Laki-laki dan Perempuan sama-sama sebagai Hamba}

Salah satu tujuan penciptaan manusia adalah untuk menyembah kepada Tuhan, sebagaimana disebutkan dalam QS. al-Dzariyat: 56

"Dan aku tidak menciptakan jin dan manusia melainkan supaya mereka mengabdi kepada-Ku."

Hamba ideal dalam al-Qur'an biasa diistilahkan dengan orang-orang yang bertakwa (muttaqun), dan untuk mencapai derajat muttaqun ini tidak dikenal adanya perbedaaan jenis kelamin, suku bangsa atau kelompok etnis tertentu. Al-Qur'an menegaskan bahwa hamba yang paling ideal ialah para muttaqun, sebagaimana disebutkan dalam QS. al-Hujurat: 13

"Hai manusia, sesungguhnya Kami menciptakan kamu dari seorang laki-laki dan seorang perempuan dan menjadikan kamu berbangsa bangsa dan bersuku-suku supaya kamu saling kenal-mengenal. Sesungguhnya orang yang paling mulia diantara kamu disisi Allah ialah orang yang paling taqwa diantara kamu. Sesungguhnya Allah Maha mengetahui lagi Maha Mengenal."

\section{b. Laki-laki dan Perempuan sebagai Khalifah di Bumi}

Maksud dan tujuan penciptaan manusia di muka bumi ini adalah, di samping untuk menjadi hamba yang tunduk dan patuh serta mengabdi kepada Allah SWT juga untuk menjadi khalifah di bumi. Kapasitas manusia sebagai khalifah di bumi ditegaskan di dalam QS. al-An'am: 165 dan QS. alBaqarah: 30.

\section{c. Laki-laki dan Perempuan Menerima Perjanjian Primordial}

Laki-laki dan perempuan sama-sama mengemban amanah. Seperti diketahui, menjelang seorang anak manusia keluar dari rahim ibunya, ia terlebih dahulu harus menerima perjanjian dengan tuhannya. QS. al-A'raf: 172 


\section{d. Adam dan Hawa, Terlibat secara Aktif dalam Drama Kosmis}

Semua ayat yang menceritakan tentang drama kosmis, yakni cerita tentang keadaan adam dan pasangannya di surge sampai keluar ke bumi, selalu menekankan kedua belah pihak secara aktif dengan menggunakan kata ganti untuk dua orang (ه)), yakni kata ganti untuk Adam dan Hawa. Dapat dilihat di QS. al-Baqarah: 35, QS. al-A'raf: 20, QS. al-A'raf: 22, QS. al-A'raf: 23, QS. al-Baqarah:187.

\section{e. Laki-laki dan perempuan berpotensi meraih prestasi}

Peluang untuk meraih prestasi maksimum tidak ada pembedaan antara laki-laki dan perempuan. Dapat dilihat di QS. Ali Imran: 195, QS. al- Nisa': 124, QS. al-Nahl: 97, QS. Ghafir: $40 .{ }^{24}$

Musdah Mulia, salah satu tokoh feminis muslim di Indonesia menyebutkan bahwa kesamaan antara perempuan dan laki-laki, terutama dilihat dari tiga dimensi. Pertama, dari segi hakikat kemanusiaannya. Dilihat dari hakikatnya sebagai manusia, Islam memberikan kepada perempuan sejumlah hak untuk meningkatkan kualitas kemanusiaannya, seperti hak mendapatkan pendidikan, hak berpolitik, dan hak-hak lain yang berkenaan dengan urusan public. Kedua, dari segi pelaksanaan ajaran agama, Islam mengajarkan bahwa perempuan dan laki-laki sama-sama mendapat pahala atau amal saleh yang diperbuatnya dan sama-sama mendapat siksaan atas pelanggaran yang mereka lakukan. Ketiga, dari segi hak-hak dalam keluarga, seperti hak waris. Islam memberikan hak waris kepada perempuan, meskipun jumlahnya tidak sebanyak yang diberikan kepada laki-laki. Sebelumnya, hak menerima warisan bagi perempuan tidak dikenal dalam tradisi Arab. Bahkan perempuan merupakan bahagian dari harta yang diwariskan. Islam juga memberikan hak kepada para istri untuk mengajukan tuntutan cerai bilamana mereka menghendaki demikian. Hak meminta cerai itu sebelumnya tidak dikenal dalam tradisi Arab. ${ }^{25}$

${ }^{24}$ Nasaruddin Umar, Argumen Kesetaraan Jender..., hlm. 248-264.

${ }^{25}$ Siti Musdah Mulia, “Kekerasan terhadap Perempuan...”, hlm. 13-14. 


\section{Periode Pertengahan}

Pada periode pertengahan ini membahas peran perempuan pada masa dinasti-dinasti Islam. Dalam buku berjudul History of Arabs karya Philip K. Hitti menjelaskan bahwa dalam sejarah kehidupan masyarakat dinasti Abbasiyah, ada budak yakni ibu Harun yang dikenal sebagai al-Khayzuran, perempuan pertama yang memiliki pengaruh penting dalam urusan kenegaraan Dinasti Abbasiyah. ${ }^{26}$

Pada masa awal Dinasti Ababasiyah, kaum wanita cenderung menikmati tingkat kebebasan yang sama dengan kaum wanita pada masa Dinasti Umayyah; tapi menjelang akhir abad ke-10, pada masa Dinasti Buwayhi, system pemingitan yang ketat berdasarkan jenis kelamin menjadi fenomena umum. Pada masa itu, banyak perempuan yang berhasil mengukir prestasi dan berpengaruh di pemerintahan, baik dari kalangan atas, seperti Khayzuran, istri al-Mahdi dan ibu al-Rasyid; 'Ulayyah, anak perempuan al-Mahdi; Zubaydah, istri al-Rasyid dan ibu al-Amin; dan Buran, istri al-Ma'mun, atau dari kalangan awam, seperti wanita-wanita muda Arab yang pergi berperang dan memimpin pasukan, menggubah puisi dan bersaing dengan laki-laki di bidang sastra, atau mencerahkan masyarakat dengan kecerdasan, musik dan keindahan suara mereka. Di antaranya adalah Ubaydah al-Thunburiyah yahng kondang di seluruh negeru pada masa al-Mu'tashim sebagai biduanita dan musisi yang cantik. ${ }^{27}$

Pada masa kemundurannya, yang ditandai dengan praktik perseliran yang berlebihan, merosotnya moralitas seksual dan berfoya-foya dalam kemewahan, posisi perempuan menukik tajam seperti yang disebutkan dalam kisah Seribu Satu Malam. Pada masa itu, perempuan ditampilkan sebagai perwujudan dari sikap licik dan khianat, serta wadah bagi semua perilaku tercela dan pemikiran yang tidak berguna. ${ }^{28}$

\footnotetext{
${ }^{26}$ Philip K. Hitti, History of The Arabs, New York: Palgrave Macmillan, edisi revisi ke-10, 2002. Penerjemah: R. Cecep Lukman Yasin dan Dedi Slamet Riyadi, (Jakarta: Serambi Ilmu Semesta, 2006), hlm. 414.

${ }^{27}$ Philip K. Hitti, History of The Arabs ..., hlm. 415.

${ }^{28}$ Philip K. Hitti, History of The Arabs ..., hlm. 416.
} 
Walaupun peartikel tidak menyebutkan secara detail satu persatu peran perempuan pada periode pertengahan ini tetapi paling tidak pembaca bisa mengetahui gambaran peran perempuan pada saat itu juga mengalami pasang surut.

\section{Periode Modern}

Periode modern yang dimaksud adalah zaman kemerdekaan. Dalam pendahuluan buku berjudul "Perempuan dan Politik dalam Islam", dikatakan bahwa saat ini gerakan perempuan sudah melewati fase kedua, yaitu dari fase pembebasan menuju fase kepemimpinan. ${ }^{29}$ Buktinya, dalam konteks kesejarahan perempuan dan politik di Indonesia masa kini, keberadaan organisasi Pusat Reformasi Pemilu (Cetro-Centre for Electoral reform) pada tahun 1999, yang dipimpin seorang perempuan antara lain penulis buku, Ani Soetjipto, telah membuktikan bahwa perempuan Indonesia telah menunjukkan keberadaannya secara konsisten sebagai "agen pembaru" di berbagai aspek kehidupan bermasyarakat, termasuk di bidang politik. Lebih jauh lagi Ani mengungkapkan bahwa pemilu langsung 2004 merupakan kontribusi dari pemerintahan (mantan) Presiden Megawati Soekarnoputri yang merupakan presiden perempuan pertama di Indonesia. ${ }^{30}$

Di lingkungan NU, perhatian besar terhadap hak-hak perempuan sudah lama bergulir. Dalam organisasi massa Islam terbesar di kawasan Asia Tenggara ini, lahirlah organisasi Muslimat, Fatayat, serta IPPNU jelas diproyeksikan untuk lebih memberikan peran kepada kaum perempuan. Sbelumnya di era pra-kemerdekaan hingga awal kemerdekaan, perempuan dianggap tidak lebih sebagai "konco wingking" (teman belakang). Keberadaan badan-badan otonom NU itu bagi kaum perempuan secara ikhlas menunjukkan dinamisasi organisasi tersebut.

Perkembangan menggembirakan tentang hak-hak perempuan dalam NU muncul dalam kesempatan Konferensi Besar Syuriah NU pada

${ }^{29}$ Zaitunah Subhan, Perempuan dan Politik dalam Islam, (Yogyakarta: Pustaka Pesantren, 2004), hlm. 1.

${ }^{30}$ Saparinah Sadli, Berbeda tetapi Setara: Pemikiran tentang Kajian Perempuan. Jakarta:PT Kompas Media Nusantara. 2010.Hlm. 108 
Sya'ban 1376 H/19 Maret 1957 M di Surabaya. Salah satu keputusannya menyebutkan bahwa kaum peremouan diperbolehkan enjadi anggota DPR/DPRD. Apalagi kemudian, keputusan Syuriah tesebut dikuatkan lagi oleh keputusan Muktamar NU 1961 di Salatiga, Jawa Tengah, bahwa seorang perempuan diperkenankan menjadi kepala desa. Bahkan, NU sudah memberikan lampu hijau atas peran serta perempuan dalam berbagai sector kehidupan, sekalipun untuk posisi kepala Negara atau presiden. ${ }^{31}$

Kini, bisa dilihat bahwa dalam berbagai sector kehidupan yang tidak bisa disebutkan semuanya dalam artikel ini, namun secara umum bisa dikatakan bahwa dalam konteks sejarah Islam perempuan sudah memperoleh kesetaraan dengan kaum laki-laki. Walaupun kadang kala masih terjadi ketidaksetaraan gender disebabkan oleh pihak yang memang tidak menghendaki kesetaraan gender dengan memanfaatkan dalil-dalil agama sebagai legitimasi ataupun yang sekedar memiliki pengetahuan yang kurang memadai tentang kesetaraan gender.

\section{F. Analisis}

Secara historis, proses penciptaan manusia telah disebutkan dalam al Qur'an. Penafsiran terhadap ayat tersebut memberi pengaruh terhadap pemahaman gender laki-laki dan perempuan. Ketika ditafsirkan bahwa Adam dan Hawa diciptakan dari jenis yang sama yaitu diri manusia maka dapat dipahami bahwa Adam dan Hawa memiliki kedudukan yang setara. Tetapi ketika ditafsirkan bahwa Hawa diciptakan dari tulang rusuk Adam, ada anggapan bahwa penafsiran tersebutlah yang mengakibatkan terjadinya subordinasi perempuan sehingga terjadi ketidakadilan gender. Tetapi ada penafsiran lain yang dibuktikan secara ilmiah, bahwa ada potensi Hawa diciptakan dari tulang rusuk Adam dapat dijelaskan melalui proses biologi yang dikenal dengan cloning. Cloning yang dimaksud ditujukan kepada salah satu hadis Nabi yang menyebutkan bahwa perempuan adalah mitra lakilaki. Mitra yang dimaksud dalam hadis tersebut dibahasakan dalam bahasa

${ }^{31}$ Said Aqil Siraj, Tasawuf Sebagai Kritik Sosial, hlm. 247-248. 
biologi yakni cloning. Sebagai mitra, tentu memiliki tingkat yang setara dan saling mnghargai satu sama lain.

Pada zaman sebelum Islam, perempuan pernah mengalami masamasa suram. Terbentuknya budaya masyarakat pada zaman jahiliyyah memposisikan perempuan sebagai sosok yang tidak berharga bahkan sampai terjadi bayi-bayi yang baru lahir dengan jenis kelamin perempuan dikubur hidup-hidup oleh orang tuanya sendiri karena dianggap tidak berguna. Perempuan tidak mempunyai ruang kebebasan dan tidak memiliki kesempatan selayaknya peran yang bisa dilakukan laki-laki. Bahkan perempuan sebagai istri bisa diwariskan dan dipertukarkan sesuka hati laki-laki tanpa meminta persetujuan istri, seolah perempuan bukan manusia.

Hingga akhirnya Nabi Muhammad SAW datang membawa ajaran Islam merubah budaya masyarakat jahiliyyah dengan ajaran yang mengangkat dan memuliakan harkat dan martabat perempuan. Dari posisi perempuan yang tidak dihargai sama sekali, yang dulunya perempuan diwariskan kepada laki-laki kemudian Islam mengangkat posisi perempuan sehingga bisa mewarisi harta setengah dari bagian laki-laki. Perempuan lebih dihargai dengan adanya hukum perkawinan Islam yang memerintahkan untuk mempergauli istri dengan baik sehingga hak-hak sebagai perempuan telah diwujudkan, tidak lagi menjadi bahan hinaan tetapi perempuan diakui keberadaannya sebagai manusia. Bahkan pada masa nabi, permpuan memiliki andil dalam berbagai sektor kehidupan sebagaimana kisah istri-istri nabi seperti khadijah yang menjadi pebisnis handal, aisyah pernah memimpin perang, dan lain sebagainya. Pada masa dinasti islam pun perempuan juga memiliki pengaruh penting dalam politik dinasti walaupun pada akhirnya juga terjadi kemunduran. Sedangkan dalam periode modern perempuan juga bisa berperan dalam berbagai sektor kehidupan termasuk menjadi kepala Negara seperti yang pernah terjadi di Indonesia yakni presiden perempuan pertama kali, Megawati Soekarnoputri. Sungguh hal ini merupakan kemajuan yang luar biasa dalam upaya penyetaraan gender. Sebagaimana yang disebutkan dalam firman Allah bahwa sesungguhnya yang paling mulia di sisi Allah adalah yang paling bertakwa, bukan karena jenis kelaminnya laki-laki bukan juga karena jenis 
kelaminnya perempuan. Sehingga dapat dirasakan hingga saat ini sudah banyak perempuan yang berkarir dengan berbagai jenis pekerjaan, misal ; dokter, dosen, guru, supir bus, kondektur, pegawai, buruh bangunan, hakim, presiden, pilot, dan profesi lainnya.

\section{G. Simpulan}

Gender adalah peran, sifat, maupun tingakah laku yang dilekatkan pada laki-laki atau perempuan yang merupakan hasil konstruksi sosial budaya.

Dalam proses penciptaan manusia yang dikisahkan dalam al-Qur'an menuai kontroversi dalam penafsiran. Terutama penafsiran al-Thabari yang menyatakan bahwa Hawa diciptakan dari tulang rusuk Adam dianggap menyebabkan subordinasi perempuan sehingga mengakibatkan ketidakadilan gender. Tetapi pendapat lain secara ilmiah bisa membuktikan bahwa bisa jadi terjadi proses cloning manusia yang dilakukan oleh Tuhan. Tetapi cloning yang dimaksud adalah mitra sehingga perempuan harus diperlakukan dengan baik.

Pada zaman pra Islam dalam budaya masyarakat Arab Jahiliyyah, perempuan mendapat perlakuan yang tidak baik, dianggap sebagai sosok yang tidak berdaya, tidak dihargai, tidak setara dengan laki-laki, ditindas dan dianggap tidak berguna bahkan aib keluarga. Tidak menunjukkan adanya kesetaraan gender.

Setelah Islam datang, kedudukan perempuan diangkat, dihargai, dilindungi, dan disetarakan dengan kaum laki-laki.

Pada periode klasik, zaman nabi, utamanya perempuan termasuk istriistri nabi memiliki peran penting dalam kehidupan pada masa itu, dalam bidang periwayatan hadis, perang, bisnis, dll bahkan perempuan mampu menjadi pemimpin dalam perang seperti yang pernah dilakukan oleh istri Nabi Aisyah.

Pada periode pertengahan, zaman dinasti-dinasti islam, perempuan juga memiliki peran penting dalam kehidupan politik bahkan mampu bersaing dalam perlombaan syair yahng kala itu menjadi trend dan bergengsi walaupun pada akhirnya mengalami kemunduran. 
Pada periode modern, masa kemerdekaan, di Indonesia peran perempuan sudah telihat dalam berbagai sector kehidupan. Salah satu organisasi yang mendukung perempuan adalah NU yang membolehkan perempuan untuk menjadi kepala desa bahkan menjadi kepala Negara. Di Indonesia pernah mempunyai Kepala Negara seorang perempuan yakni Megawati Soekarnoputri.[]

\section{Daftar Pustaka}

Arif, Syamsuddin, Orientalis \& Diabolisme Pemikiran. Jakarta: Gema Insani Press, 2008.

Arif, Syamsuddin, "Wanita dan Keluarga Citra Sebuah Peradaban", Al-Insan, Jumal Kajian Islam, Jakarta: Lembaga Kajian dan Pengembangan Al-Insan. N0. 3, Vol. 2. 2006.

Azra, Azyumardi, Islam Substantif. Agar Umat Tidak Jadi Buih, Jakarta: Mizan. 2000.

Engineer, Asghar Ali. Pembebasan Perempuan, Yogyakarta: LKis.1999

Faqih, Mansour, Analisis Gender \& Transformasi Sosial, Yogyakarta: Pustaka Pelajar, 2007.

Hitti, Philip K. History of The Arabs,.New York: Palgrave Macmillan, edisi revisi ke-10.2002. Penerjemah: R. Cecep Lukman Yasin dan Dedi Slamet Riyadi. Jakarta: Serambi Ilmu Semesta, 2006.

Ismail, Nurjannah, Perempuan dalam Pasungan Bias Laki-laki dalam Penafiran, Yogyakarta: LKiS, 2003.

al-Masyri, Nasy'at, Nabi Suami Teladan, terj. Salim Basyarahil, Jakarta: Gema Insani Press, 1989.

Monib, Mohammad dan Bahrawi Islah, Islam dan Hak Asasi Manusia dalam Pandangan Nurcholish Madjid. Jakarta: Gramedia Pustaka Utama. 2011.

Mulia, Siti Musdah, "Kekerasan Terhadap Perempuan Mencari Akar Kekerasan dalam Teologi", SAWWA Jumal Studi Gender, PSG IAIN Walisongo Semarang, Vol. 3. No.1, 2008. 
Sadli, Saparinah, Berbeda tetapi Setara: Pemikiran tentang Kajian Perempuan. Jakarta: Kompas Media Nusantara. 2010.

Shihab, Quraisy, Wawasan al-Qur'an: Tafsir Tematik atas Pelbagai Persoalan Umat, Jakarta: Mizan.

Siroj, Said Aqil. Tasawuf Sebagai Kritik Sosial, Bandung: Mizan.2006

Starda, Ronni, Sabda Nabi tentang Perempuan, Serumpun Bunga dari Rasulullah, Jakarta: Elex Media Komputindo, 2010.

Subhan, Zaitunah. Perempuan dan Politik dalam Islam, Yogyakarta: Pustaka Pesantren, 2004.

Syukur, Fatah, Sejarah Peradaban Islam, Semarang: Pustaka Rizki Putra. 2011.

Umar, Nasaruddin, Argumen Kesetaraan Jender Perspektif al-Qur'an, Jakarta: Paramadina, 2001. 
